\title{
Addiktiot elämän tarkoituksena
}

Tammi, Tuukka \& Raento, Pauliina (toim.) (2013):

Addiktioyhteiskunta: Riippuvuus aikamme ilmiönä.

Gaudeamus: Helsinki. 258 s.

ISBN 978-952-495-312-2.
IHMISLAPSEN kehittymisessä sikiöstä täysikasvuiseksi ihmisyksilöksi on kolme haastetta: halu, nautinto ja separaatio. Ne ovat kolme perustavaa kehityksen ulottuvuutta. Toisin sanoen ihmisen on opittava elämään halunsa ja nautintonsa kanssa suhteessa toisiin, erottautuen toisista ja liittyen heihin.

Jokainen ihminen kohtaa haasteet universaalisti. Siksi jokaisen yhteiskunnan on kaikkina aikoina kaikissa paikoissa myös vastattava niihin. Yksilö ei kohtaa halunsa, nautintonsa ja erillisyytensä ongelmia tyhjiössä, vaan käytettävissä olevat ratkaisumallit ja ratkaisutavat ovat aina enemmän tai vähemmän kollektiivisia.

Tästä näkökulmasta katsottuna artikkelikokoelma Addiktioyhteiskunta kertoo niistä kollektiivisista puitteista, joissa jokaisen meistä on kohdattava halunsa, nautintonsa ja erillisyytensä. On syytä painottaa, että esimerkiksi tapamme nauttia liittyy oleellisesti tapaamme haluta ja erottautua toisista sekä samastua ja liittyä heihin.
KOKOELMA ERILLISIÄ

\section{NÄKÖKULMIA}

Addiktioyhteiskunnan ytimessä oleva addiktion käsite liittyy kaikessa epämääräisyydessään oleellisesti niin haluun, nautintoon kuin separaatioonkin: addiktoidumme johonkin, mikä tuottaa nautintoa ruumiillemme ja mitä haluamme tuon nautinnon takia.

Teoksessa ilmiötä lähestytään pääosin yhteiskunnallisesta näkökulmasta, kuten kirjan nimikin osoittaa. Artikkelien kirjoittajat ovat suurimmalta osin yhteiskuntatieteiden edustajia. Tämä on kokonaisuuden kannalta sekä etu että puute. Toisaalta yhteinen tausta lähentää kirjoittajien näkökulmia toisiinsa ja tukee näin kokonaisuuden yhtenäisyyttä, toisaalta ainakin lääkärilukijan korvaan särähtelee useissa kohdissa kirjoittajien ulkokohtainen luentotyyli, josta paistaa läpi kokemattomuus siitä, mistä puhutaan.

Yksi olennaisimmista huomioista on, että tyypilliseen suomalaiseen tapaan kirja on koottu yhteen erillisistä näkökulmista. Kyse ei ilmiselvästikään ole yhteisestä projektista, jossa eri kirjoittajat vaikuttaisivat toisiinsa ja keskustelisivat keskenään yhteisestä aiheesta. Nyt jokainen esittelee näkemyksensä omasta suppeahkosta aiheestaan ilman, että näkökulmia yritettäisiin yhdistää tai toisten esityksiä mitenkään kommentoitaisiin. Tämä vaatisi tietenkin hyvin toisenlaista projektia ja tapaa kirjoittaa ja ajatella.

\section{KESKUSTELUNAVAUKSIIN ARJEN KOKEMUKSIA}

Toinen huomioni vilahtikin jo edellä: kirja olisi hyötynyt oleellisesti ruohonjuuritasolla addikitoiden parissa työskentelevien näkemyksistä. Miltä addiktioyhteiskuntamme näyttää A-klinikan päihdehoitajan, lastensuojelun sosiaalityöntekijän, etsivän nuorisotyön sosiaaliohjaajan tai psykiatrisen päivystyksen lääkärin näkökulmasta? Tai mitä aiheesta sanoisi narkomaanin äiti tai pelikoneensa ääreen vetäytyneen koulusta kieltäytyjän isä? Tai entä addiktioiden kokemusasiantuntijat itse, miten he näkevät tilanteensa ja yhteiskunnan, jossa elävät?

Näistä kehittämismahdollisuuksista huolimatta Addiktioyh- 
teiskunta sisältää hyviä keskustelunavauksia. Arto Ruuskan ja Pekka Sulkusen artikkeli Addiktiosairaus ja moraali lähestyy tärkeää ja aina moniulotteista rajaa alkoholin käytön medikalisoinnin ja moralisoinnin välillä historiallis-filosofisesta näkökulmasta. Näkökulmaa olisi helppo laajentaa ja syventää sekä filosofisesti että esimerkkiaddiktioista alkoholin käytön ulkopuolellekin. Toisaalta kysymys alkoholin käytön medikalisoitumisesta ja asettumisesta moraaliseen viitekehykseen on niin laaja ja olennainen, että sille itsessään voisi hyvin omistaa ison monitieteellisen tutkimusprojektin.

Matias Karekallaksen ja Atte Oksasen eräänlainen rinnakkaisten tapaustutkimusten muodostama Addiktion paikka populaarimusiikissa on sattumoisin ajankohtainen rock-legenda Lou Reedin äskettäisen kuolemankin takia. Rockin ja päihteiden historian kietoutuminen toisiinsa on sinänsä jo ilmiö, jonka pitäisi saada taiteidentutkijoiden sormet syyhyämään.

Frans Mäyrän Aika, raha ja peliviihde keskittyy puolestaan alaotsikkonsa mukaisesti "verkkopelaamisen harmeihin ja harmittomuuteen”. Hänenkin näkökulmansa laajentaminen ja syventäminen olisi itsessään lähtökohta laajalle tutkimusprojektille. Kuka tahansa lapsiperheiden parissa työskentelevä ymmärtää, että lähes jokaisessa lapsiperheessä joudutaan päättämään joko sanoitetusti tai sanoittamatta, mitä tehdään pelimaailman kanssa kaikkine sen addiktoivine puolineen.

\section{NAUTINTO OHJAA ARVOMUUTOSTA}

Kokonaisuudessaan Addiktioyhteiskunta-kokoelman punaiseksi langaksi näyttäisi muodostuvan kuva, jossa lisääntyvät keinot tuottaa nautintoa ja näiden keinojen myötä paisuva nautinto muodostavat yhteisöllisen elämän kokemuksellisen keskiön.

Tämä huomio itsessään merkitsee historiallista muutosta siinä, miten ihmisyhteisöt jäsentävät olemistaan. Asia on kaikille tuttu: kun ihmislaji on kulttuurisen evoluution myötä päässyt irti tilanteesta, jossa keskitytään biologisten perustarpeiden tyydyttämiseen, se, mikä on enemmän kuin välttämättömien tarpeiden tyydyttämistä, on tullut aina vain tärkeämmäksi.

Samalla ihmisten eriarvoistumisen lisääntyminen tarkoittaa sitä, että kuilu perinteisen "tarveyhteiskunnan" ja uudemman "addiktioyhteiskunnan" välillä kasvaa. Tarveyhteiskunnassa tehostetaan addiktoituneen Euroopan eristämistä tarpeidensa tyydyttämättömyyden keskellä kärsivästä Afrikasta ja mietitään, miten rahoitetaan kaikki ne vaipat ja ennen kaikkea kaikki vaippoja vaihtavat kädet, joita jatkuvasti kasvava vanhusväestö tarvitsee.
Samalla addiktioyhteiskunnassa muodostetaan kriteereitä laihuusleikkauksiin pääsemiseksi, säädetään ikärajoja peleille ja elokuville ja yritetään luokitella muuntohuumeet juridisesti mahdollisimman nopeasti elintarvikkeista huumausaineiksi.

Tämä osoittaa, että Addiktioyhteiskunnan kuvaama problematiikka on itse asiassa tarveyhteiskunnan sisään rakentuva lisäulottuvuus, ja että addiktioyhteiskunta edellyttää edes jollain tavalla toimivaa tarveyhteiskuntaa.

Addiktioyhteiskunta ei siis olekaan jokin uusi yhteiskuntamuoto, vaan jo ennestään moniulotteisen yhteiskunnan uusi, merkittävä ulottuvuus, josta länsimainen keskiluokka etsii lisääntyvässä määrin elämänsä ja olemassaolonsa tarkoitusta. Toisin sanoen, kun usko tuonpuoleiseen elämään rapistuu, keskiluokkakin haluaa nautintoa jo tämänpuoleisessa. Koska kirkko ja uskonto eivät tällaisessa tilanteessa pysty tarjoamaan koordinaatteja elämän elämiselle, on addiktioyhteiskunnan ne tarjottava.

Panokset Addiktioyhteiskunnassa ovat siis valtavat, itse asiassa paljon suuremmat kuin tutkijat itse aukikirjoittavat. Siksi ja siten kirja on tärkeä, mutta itsessään riittämätön puheenvuoro keskustelussa, jonka soisi jatkuvan, laajenevan ja syvenevän.

Janne Kurki

dosentti, FT, LL 